\title{
SIMULINK SOFTWARE FEATURES FOR MODELLING A SMALL-SIZE LOADER
}

\author{
O. Yefymenko, PhD., Assoc. Prof., A. Hrichchina, Assist. Prof., \\ Kharkiv National Automobile and Highway University
}

\begin{abstract}
Computer simulation as a tool to determine the loading for implements and hydraulic drives of small-size loaders has been considered in the paper. A number of lifting mechanism design models has been built; their strengths and shortcomings have been analysed. It has been proposed to alter the machine's hydraulic drive design as well as to redesign the arm and the levelling mechanism to improve reliability of a small-size loader.
\end{abstract}

Key words: small-size loader, computer simulation of road-building machines, analysis, arm, pump capacity.

\section{ОСОБЛИВОСТІ ВИКОРИСТАННЯ SIMULINК ДЛЯ МОДЕЛЮВАННЯ МАЛОГАБАРИТНОГО НАВАНТАЖУВАЧА}

\author{
О.В. Сфименко, доц., к.т.н., А.В. Гріччіна, ст. викл., \\ Харківський національний автомобільно-дорожній університет
}

Анотація. Розглядається завдання визначення навантаженості робочого устаткування й гідроприводу малогабаритного навантажувача за допомогою комп'ютерного моделювання. Побудовано моделі різного компонування піднімальних механізмів, проаналізовано переваги й недоліки кожної з них. Запропоновано конструктивно змінити гідропривід матини й конструкцію стріли та зрівняльного пристрою.

Ключові слова: малогабаритний навантажувач, комп'ютерне моделювання БДМ, аналіз, стріла, продуктивність насоса.

\section{ОСОБЕННОСТИ ИСПОЛЬЗОВАНИЯ SIMULINК ДЛЯ МОДЕЛИРОВАНИЯ МАЛОГАБАРИТНОГО ПОГРУЗЧИКА}

\author{
А.В. Ефименко, доц., к.т.н., А.В. Гриччина, ст. преп., \\ Харьковский национальный автомобильно-дорожный университет
}

Аннотация. Рассматривается задача определения нагруженности рабочего оборудования и гидропривода малогабаритного погрузчика с помощью компьютерного моделирования. Построены модели различной компоновки подъемных механизмов, проанализированы достоинства и недостатки каждой из них. Предложено конструктивно изменить гидропривод машины и конструкиию стрель и уравнительного устройства.

Ключевые слова: малогабаритный погрузчик, компьютерное моделирование СДМ, анализ, стрела, производительность насоса.

\section{Introduction}

High performance of a loader largely depends on the design of the hydraulic drive. In heavy loading operations the hydraulic drive of the working equipment operates $80-85 \%$ of the total length of the working cycle. The turn-on fre- quency of the hydraulic drive is $600-900$ per hour. Hydraulic drive is the main actuating device for the working equipment of all road and construction machines in general and particularly loaders. Therefore, engineers are constantly working on its improvement. This makes the topicality of the presented paper. 


\section{Analysis of Publications}

Basic principles of mathematical modelling of hydraulic drives used in road and construction machines were discussed in paper [1]. The drawback of this method is the calculation of road and construction machines' hydraulic drive loads in the form of static values that do not consider the workflow dynamics of modern machines. In papers [2-4] MATLAB 6 and SolidWorks computer modelling features for dynamic processes in hydraulic drive loading were described.

\section{Purpose and Tasks}

The purpose of the paper is to develop a computer model of the hydraulic drive and to analyse the model in terms of improving the reliability and performance of the loader.

The tasks include: 1) overview of software packages applied for computer-aided design of hydraulic drives; 2) design of the loader components and determination of their parameters; 3 ) development of a computer model of the hydraulic drive; 4) optimization of both the hydraulic drive parameters and working equipment designs.

\section{Hydraulic Drive Models for Road and Con- struction Machines}

The aim of computer modelling is to reduce both the expenses needed for numerous experiments and the hydraulic drive design time. The paper deals with the analysis of three different hydraulic drive CAD-systems (FLOW-3D, SIMULINK and COSMOSFloWorks). SIMULINK was selected for modelling due to its following advantages: simplicity, user friendly interface, block modelling system.

A two-module machine with a process module «Т16МГ Universal loader» with the bucket capacity of $0.165 \mathrm{~m}^{3}$ was chosen as an object of the study. The mathematical model of the loader's working equipment with three joint coordinates was applied for the analysis. It was built on the basis of Lagrange equation of the second type.

With the help of Simulink blocks the hydraulic drive models were built: models with one, two, four hydraulic cylinders, a model of the existing machine. A model of the loader's working equipment is composed of a hydraulic pump, hydraulic cylinders and a crossbeam. It simulates the operation of the hydraulic drive when the lifting arm is being raised with the load.

A model with one hydraulic cylinder is composed of a single-acting cylinder with a return spring (Figure 1).
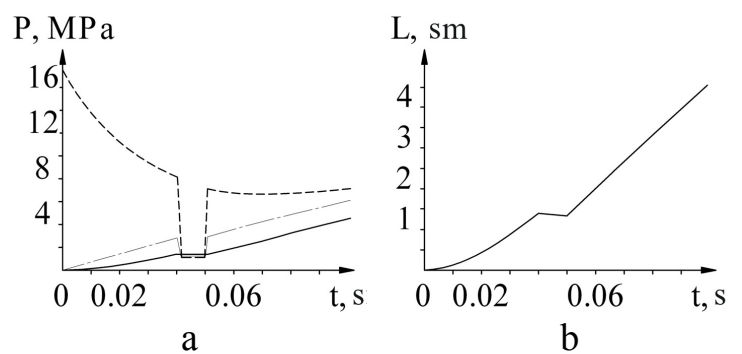

Fig. 1 Pressure curve (a) and cylinder rod travel curve (b)

The curve shows that at $\mathrm{T}=0.04 \mathrm{sec}$ (time of operation) compression begins at the inlet of the pump, and at $\mathrm{T}=0.05 \mathrm{sec}$ it is removed. The value of the feed pressure $\rho_{1}$ drops rapidly. The pressure chart for the $\rho_{2}$ cylinder piston side does not show such a rapid change. Pressure almost did not change in the $\rho_{3}$ cylinder rod side. This can be explained by the fact that the outage of the hydraulic pump operation was short. Figure (b) confirms the pressure drop in the pressure line and the piston side as the piston changed its direction for a short time under the action of the return spring.

A model with four hydraulic cylinders is composed of a single-acting cylinder with a return spring and different output parameters. This model is compared favourably with the previous one because the operation of four hydraulic cylinders is simulated in it. This model gives an opportunity to compare the work of hydraulic cylinders with various parameters. Cylinder piston travel curves with different parameters are shown in Figure 2.

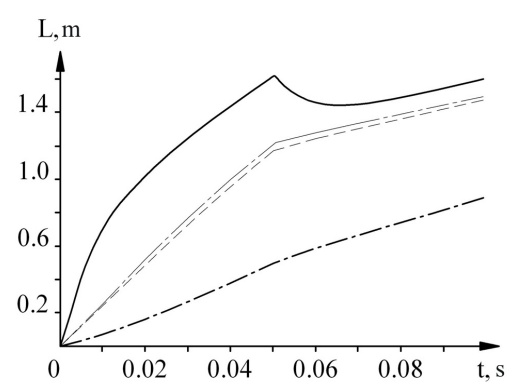

Fig. 2. Cylinder rod travel curve with different parameters 
The machine implements model simulates the operation of the hydraulic drive at lifting the loader arm with a full bucket. The beam (arm) travel curves as well as the angles of the beam position relative to the horizon in radians are displayed on the oscilloscopes. In developing this model of the hydraulic drive some assumptions were made:

- the loader arm was taken as an absolutely rigid (nondeformable) beam placed perpendicular to the longitudinal axis of the loader;

- the hydraulic cylinders were placed so that when the arm is raised, the piston cavity is working;

- the sum of the arm's weight and the loader's maximum load carrying capacity was taken as the cargo weight in the model.

Another purpose of the research was to study the effect of the arm speed on the working processes. The influence of the pump feed changes on the hydraulic drive operation was studied. The load is in the centre of the beam. The following pumps were used here: Gear Pump-32, Gear Pump-46, Gear Pump-67, Gear Pump-98 (Figure 3). The obtained values show that with increasing the hydraulic pump feed the arm lifting speed rises, though the amplitude of the beam angle oscillations also increases (Table 1).
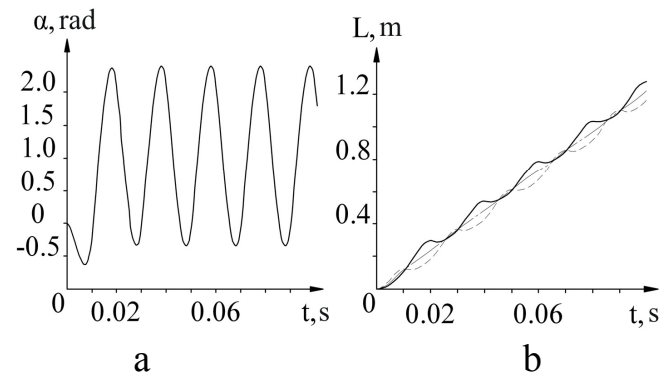

Fig. 3. Angle curve (a) and crossbeam travel curve (b) with a HШ-32 pump

The obtained values show that at increasing the hydraulic pump feed the arm lifting speed rises, though the amplitude of the beam angle oscillations also increases (Table 1).

Table 1 Values of the beam's average travel speed and angle amplitudes that were obtained

\begin{tabular}{|c|c|c|c|}
\hline $\begin{array}{l}\text { Hydraulic } \\
\text { drive }\end{array}$ & $\begin{array}{l}\text { Feed, } \\
\mathrm{m}^{3} / \mathrm{s}\end{array}$ & $\begin{array}{l}\text { Amplitude of } \\
\text { angle oscilla- } \\
\text { tions, rad }\end{array}$ & $\begin{array}{c}\text { Beam travel } \\
\text { speed } \Delta z \\
\text { m/s. }\end{array}$ \\
\hline $\begin{array}{c}\text { Gear } \\
\text { Pump-32 }\end{array}$ & 0.00053 & $\begin{array}{c}{\left[+2.4 * 10^{-4} ;-\right.} \\
\left.0.5^{*} 10^{-4}\right]\end{array}$ & 0.012 \\
\hline $\begin{array}{c}\text { Gear } \\
\text { Pump-46 }\end{array}$ & 0.00078 & $\begin{array}{c}{\left[+3.5^{*} 10^{-4} ;-\right.} \\
\left.1.3^{-4} 10^{-4}\right]\end{array}$ & 0.0225 \\
\hline $\begin{array}{c}\text { Gear } \\
\text { Pump-67 }\end{array}$ & 0.00112 & $\begin{array}{c}{\left[+4.2 * 10^{-4} ;-\right.} \\
\left.2 * 10^{-4}\right]\end{array}$ & 0.0365 \\
\hline $\begin{array}{c}\text { Gear } \\
\text { Pump-98 }\end{array}$ & 0.00165 & $\begin{array}{c}{\left[+4 * 10^{-4} ;-\right.} \\
\left.3.6 * 10^{-4}\right]\end{array}$ & 0.056 \\
\hline
\end{tabular}

In the model the arm is lifted while the bucket is fully loaded. The centre of gravity of the bucket (beam) is displaced to the right edge at a distance of $1 / 3$ from the right edge of the bucket. This may be due to the heterogeneity of the material being developed, such as construction waste. The parameters of the loading process were analysed with changes of displacements $\mathrm{zb}$ and za depending on the increase of the hydraulic cylinder piston area (Figure 4).
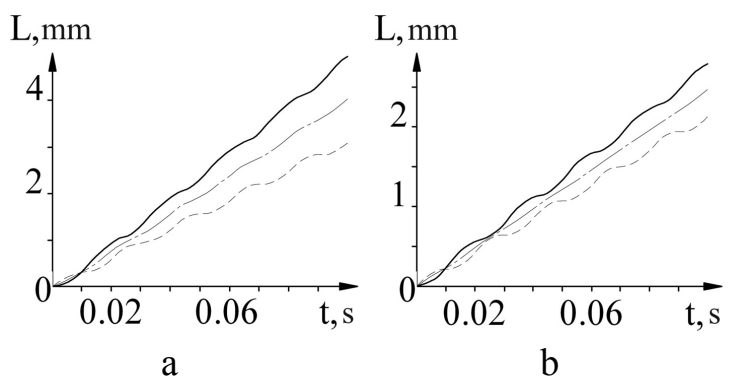

Fig. 4. Crossbeam travel curves at $\mathrm{M}=1200 \mathrm{~kg}$ using hydraulic cylinders of $\mathrm{D}=100 \mathrm{~mm}$ (a) and $\mathrm{D}=125 \mathrm{~mm}$ (b)

The curves given above show that when the piston area was increased, the difference between the displacement coordinates $\mathrm{zb}$ and za was decreased from $0.0028 \mathrm{~m}$ to $0.001 \mathrm{~m}$ at $\mathrm{T}=0.1 \mathrm{~s}$. Since the smallest difference between the values $\mathrm{zb}$ and $\mathrm{za}$ is $0.001 \mathrm{~m}$ was observed in this latter case, it is advisable to use the hydraulic cylinder of $\mathrm{D}=125 \mathrm{~mm}$ (Table 2).

Таблиця 2 Model examination data with center-of-gravity shifts

\begin{tabular}{|c|c|c|c|c|c|}
\hline $\begin{array}{c}\text { Piston } \\
\text { diame- } \\
\text { ter D, m }\end{array}$ & $\begin{array}{c}\text { Weight of } \\
\text { cargo, } \mathrm{kg}\end{array}$ & $\begin{array}{c}\Delta \mathrm{z}, \\
\mathrm{m} / \mathrm{s}\end{array}$ & $\begin{array}{c}\mathrm{z}_{\mathrm{b}}, \\
\mathrm{m}\end{array}$ & $\begin{array}{c}\mathrm{z}_{\mathrm{a}}, \\
\mathrm{m}\end{array}$ & $\begin{array}{c}\mathrm{z}_{\mathrm{b}}-\mathrm{z}_{\mathrm{a}}, \\
\mathrm{m}\end{array}$ \\
\hline 80 & 985 & 0.061 & 0.0075 & 0.0047 & 0.0028 \\
\hline 100 & 985 & 0.043 & 0.0053 & 0.0033 & 0.002 \\
\hline 125 & 985 & 0.027 & 0.0032 & 0.0022 & 0.001 \\
\hline 100 & 1200 & 0.04 & 0.005 & 0.003 & 0.002 \\
\hline 125 & 1200 & 0.025 & 0.003 & 0.0021 & 0.0007 \\
\hline
\end{tabular}

The analysis of the research data proved that increased weight of cargo does not significantly affect the arm lifting speed in these operating modes. However, the use of hydraulic cylinders with a piston diameter of $\mathrm{D}=125 \mathrm{~mm}$ with the given cargo weight compensates for the overload caused by the centre-of-gravity shift, since the value of the za-zb difference in this case is the smallest. 


\section{Conclusion}

The computer model analysis of the loader drive system showed that in order to increase the efficiency of the existing design of the loader it is necessary:

- to change the position of the hydraulic cylinders which lift the arm in such a way that a piston cavity will become the working cavity of the hydraulic cylinder when lifting the arm;

- to replace a Gear Pump-32 pump with a Gear Pump-67 pump in order to increase the arm lifting speed;

- when using a loader to move nonhomogeneous materials, for example construction wastes, it is advisable to provide a Gear Pump-67 hydraulic pump and hydraulic cylinders with a diameter of a piston $\mathrm{D}=125 \mathrm{~mm}$ as parts of the hydraulic drive system.

This is due to the nonuniform distribution of the material in the loader bucket. As a result, there is a tilt of the frame and hydraulic cylinders. Whereas, when the power on the hydraulic cylinder rods increases, the lifting capacity of the hydraulic drive increases, too. Therefore, it is advisable to increase the strength characteristics of the loader frame or to change the design of the frame. With such a layout of the hydraulic drive we can use the frame design (Figure 5).

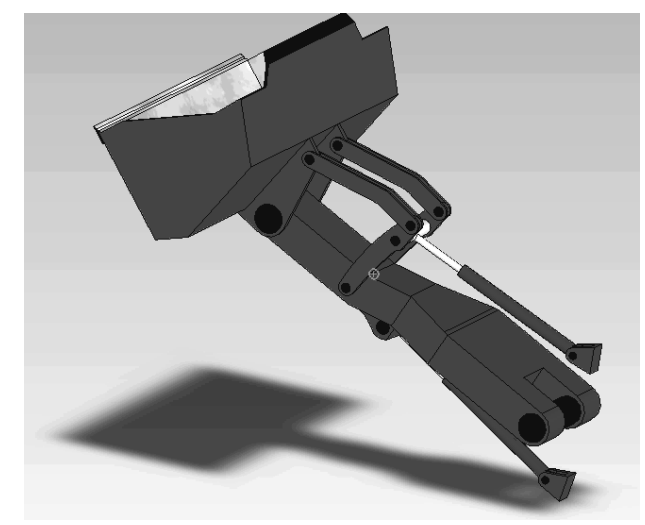

Fig. 5. Proposed design of a loader implement

Its advantage is that in case of implements tilting, the main load is concentrated not on the hydraulic drive but on the steel structure of the arm.

\section{References}

1. Вильнер Я.М. Справочное пособие по гидравлике, гидромашинам и гидроприводам / Я.М. Вильнер, Я.Т. Ковалёв, Б.Б. Некрасов; под ред. Б.Б. Некрасова. - Минск: Высшая школа, 1976. - 416 с.

2. Дияконів В.П. MATLAB 6/6.1/6.5 + Simulink 4/5 у математику й моделюванні: повний посібник користувача / В.П. Дияконів. - М.: Солоний-Пресс. 2003. - $576 \mathrm{c}$.

3. Черных И.В. SIMULINK: среда создания инженерных приложений / И.В. Черных; под общ. ред. к.т.н. В. Г. Потёмкина. М.: ДИАЛОГ-МИФИ, 2003. - 496 с.

4. SolidWorks. Компьютерное моделирование в инженерной практике / А.А. Алямовский, А.А. Собачкин, Е.В. Одинцов и др. - С.Пб.: БХВ-Петербург, 2005. $800 \mathrm{c}$.

\section{References}

1. Vilner Ja. M., Kovaljov Ja. T., Nekrasov B.B. Spravochnoe posobie po gidravlike, gidromashinam $i$ gidroprivodam [Hydraulic Machines and Drives Handbook]. Minsk, Vysshaja shkola Publ., 1976. $416 \mathrm{p}$.

2. Dyiakoniv V. P. MATLAB 6/6.1/6.5 + Simulink 4/5 u matematyku y modeliuvanni. Povnyi posibnyk korystuvacha [MATLAB 6/6.1/6.5 + Simulink 4/5 in Mathematics and Modelling. Complete User Guide]. Moscow, Solonyi-Press Publ., 2003. 576 p.

3. Chernyh I. V. SIMULINK: sreda sozdanija inzhenernyh prilozhenij [SIMULINK: Environment for Creating Engineering Applications]. Moscow, DIALOG-MIFI Publ., 2003. 496 p.

4. Aljamovskij A. A., Sobachkin A.A., Odincov E.V., Haritonovich A.I., N.B. Ponomarev. SolidWorks. Kompjuternoe modelirovanie $v$ inzhenernoj praktike [SolidWorks. Computer Modelling in Engineering]. Sankt-Peterburg, BHV-Peterburg Publ., 2005. 800 p.

Рецензент: Е.М. Венцель, профессор, д.т.н., ХНАДУ. 